\title{
Effects of Human Capital on Economic Growth in Selected Asian Countries
}

\author{
Nazife Özge Beşer ${ }^{a}, \mathrm{~b}$, Murat Beşerc
}

\section{Özet}

Dünyada yapılan araştırmalarda ülkelerin iktisadi kalkınması üzerinde beşeri sermayenin önemli payının olduğu vurgulanmaktadır. Özellikle 20.yy ortalarından itibaren ülkelerin kalkınma ve büyüme sürecinde yaşadıkları sorunların çözümünde beşeri sermaye dikkat çekmeye başlamıştır. Büyümenin itici gücü olan faktörlerin birikimini ve büyüme sürecinin işleyişini araştıran İçsel Büyüme Teorisi, ekonomilerde yaşanan büyüme sürecinde fiziki sermaye ile açıklanamayan faktörlerinde var olduğu düşüncesine dayanmaktadır. Günümüz ekonomilerinin büyüme süreçlerinde de büyük bir yere sahip olan beşeri sermaye faktörü çalışmada insani gelişim endeksi olarak ele alınmış ve ekonomik büyüme üzerindeki etkisi seçilmiş 5 Asya Ülkesi (Hong Kong, Japonya, Çin, Singapur, Kore) için 1990-2016 yılları arasında panel veri analizi yardımıyla incelenmiştir. Değişkenler için öncelikle yatay kesit bağımlılığı ve homojenlik testleri yapılmıştır. Paneli oluşturan ülkeler arasında yatay kesit bağımlılı̆̆ı tespit edildiği için serilerin durağanlığını incelemek üzere yatay kesit bağımlılığını dikkate alan ikinci nesil birim kök testlerinden HadriKruzomi testi ve nedensellik testi için ise Emirmahmutoğlu ve Köse (2011) nedensellik testi kullanılmıştır. Analiz sonuçlarına göre ekonomik büyümeden insani gelişim endeksine doğru tek yönlü nedensellik ilişkisi tespit edilmiştir.
Anahtar Kelimeler

İçsel Büyüme Teorisi

Beşeri Sermaye

Ekonomik Büyüme

Panel veri Analizi

Makale Hakkında

Geliş Tarihi: 15.02.2019

Kabul Tarihi: 24.04.2020

Doi: 10.18026/cbayarsos.527865

\section{Effects of Human Capital on Economic Growth in Selected Asian Countries}

\begin{abstract}
In researches which are conducted in the world, it has been pointed out that there is an important share of human capital on countries' development. Especially since the middle of $20^{\text {th }}$ centuries, human capital had been stared to get attention in solving problems which countries went through during development and growth. Intrinsic Growth Theory that searches savings of factors which are driving power of growth and mechanism of growth process has been based on thought which there is also factors that cannot be explained by physical capital in the growth process of economies. Human capital factor which has also a big place in growth processes of today's economies had been taken as humanitarian development index and effect on economic growth had been chosen; it had been analyzed for 5 Asian countries (Hong Kong, Japan, China, Singapore, Korea) in between years of 1990 and 2016 by the help of panel data analysis. Firstly, cross-sectional dependency and homogeneity tests had been performed for variables. Since cross- sectional dependency was found between countries constituting the panel, Hadri-Kruzomi (2012) test which is one of secondgeneration unit root tests and considers cross-sectional dependency had been used to examine the stability of series and Emirmahmutoğlu and Köse (2011) causality test had been used for causality test. According to analysis results, unidirectional causality relation had been determined from economic growth to humanitarian development index.
\end{abstract}

Keywords

Intrinsic Growth Theory

Human Capital

Economic Growth

Panel Data Analysis

About Article

Received: 15.02 .2019

Accepted: 24.04 .2020

Doi: 10.18026/cbayarsos.527865

a İletişim Yazarı: nokilic@agri.edu.tr

b Dr. Öğr. Üyesi, Ağrı İbrahim Çeçen Üniversitesi/ İktisadi ve İdari Bilimler Fakültesi, 0000-0002-6738-3638.

c Dr. Öğr. Üyesi, kurumu/ Ağrı İbrahim Çeçen Üniversitesi/ İktisadi ve İdari Bilimler Fakültesi, 0000-0002-8487-4586. 


\section{Introduction}

Intrinsic Growth models had taken place in economy literature by years of 1980 and 1990 when liberalization movements accelerated. Economic growth is an economic indicator that is arrived at a consensus in point performance of world economies' situation. Dynamics of such an important indicator has taken place in focus of economists all along. At this point, intrinsic growth models had brought a new dynamic to economic growth concept and it has been gone to look the source of growth into intrinsic factors.

Conducted studies have revealed the effects of social factors besides physical factors in countries' economic growths. Intrinsic growth models that does not reject neo-classic growth models has strengthen the basics of neo-classic growth and had placed the human capital concept to basis of economic growth. Economic growth has occurred by taking action of these qualified education system which is source of growth, quality health system, technologic development based on R\&D and economic growth in intrinsic growth models that based on public policies which support all of them. Important point in intrinsic growth is qualitative development rather than numerical development. Being high of schooling rates, literacy rates are not effective in economic growth by oneself. What is important here is qualified literacy and schooling rates which all needs are covered. While raising individuals who has analytic thinking ability is based on firstly sufficiency of health indicator, it is the most important source of human capital. Thus, fund of knowledge can be performed by relevant education system. Fund of knowledge and human capital which are constituted as part of qualified education system has also created the source of technologic development. Production increases that mentioned technologic development will provide have also strengthen the R\&D initiatives and economic growth has occurred by promoting this loop with public investments.

Intrinsic growth theory which is developed by Romer against Neo-Classic Growth Theories that explain the economic growth by physical production factors has suggested that human capital has also an important place in economic growth dynamics. Human capital investments that countries made to improve the qualification of manpower in this context have affected the economic growth by providing adoption of new product and technologies.

Human capital factor that has a big place in growing processes of today's economies has been discussed as humanitarian development index and it had been examined for 5 Asian countries (Hong Kong, Japan, China, Singapore, Korea) which effect on growth rate was chosen in between years of 1990 and 2016 by the help of panel data analysis. According to analysis results, unidirectional causality relation had been determined from economic growth to humanitarian development index.

\section{Intrinsic Growth Models}

Intrinsic Growth Models assume that economic powers which operate in market mechanism specify the economic growth as internal and define the intrinsic growth as driving power of economic growth (Ercan, 2000). Elements of economic growth of intrinsic growth concept that is started with P. Romer (1986) and R. Lucas (1988) and developed in years of 1990 had been searched in the system. Intrinsic growth concept consists of modelling variables such as education, health, $R \& D$, technologic innovations, new role of government, fund of knowledge, financial innovations, economies of scale and distribution of income (Berber, 2006). Intrinsic growth theories have rejected the exteriority of technologic developments and has included that to model (Karabulut and Emsen, 1997). 
Basic identifiers of intrinsic growth have been gathered in three groups as education policy, health policy and technology policy beside countries' religious, regional and cultural factors have been also identified as basic identifiers of intrinsic growth. Working of these factors have revealed education, health and expenses which are done to technologic background and it has occurred as that activates the search and development activities. New products have been found at the result of mentioned process, more effective production methods have been developed or existing products have been improved and economic growth has occurred (Kibritçioğlu, 1998).

The concept of human capital, which constitutes one of the main sources of economic growth, is used to express all the concepts such as knowledge, skills, abilities, health status, place in social relations and education level of the individual or society. In response to this emergence of internal growth theory, Mankiw, Romer and Weil (1992) empirically tested the neoclassical growth theory to include human capital. The authors state that the power of neo-classical growth theory, expanded with human capital, to explain real life is greatly increased. Barro (1991) states that the inclusion of human capital in the model does not change the results and predictions of the neo-classical theory unless there is an increasing return (Taban and Kar, 2006).

The importance of human capital has been pointed out in intrinsic growth models. Human capital concept that constitutes the primary resource of economic growth has been used to define all concepts as individual's or society's knowledge, skill, abilities, health situation, place in social relations and education level. In near past, Lucas (1988) and Rebelo (1991) had counted human capital as one of production factors such as physical capital. How economy needs physical capital investments, it has also needed human capital investments. Concept emphasized as human capital has showed up or it may also come into being by itself with learning by doing in study process. Investments which are made to human capital had been defined as opportunity cost of spending time in education (Kar and A $\breve{g r}, 2003: 6)$. Lucas had indicated that increase in individual's human capital contributed to productivity of all production factors in reality except that it increase the self-productivity, every type of investments that government will make in education and to develop the background of technology will affect growth more than investments on physical capital by making positive effects on human capital accumulation. According to approach of Lucas, production function is as follows when production level $(\mathrm{Y})$, physical capital $(\mathrm{K})$ and efficient labor $\left(\mathrm{N}_{\diamond}\right)$ is in an economy that neo-classic market conditions are valid:

$Y=F\left(K, N_{\curvearrowright}\right)$

Concentration in model is on explanation of effective labor. Effective labor stock in country has been defined as $\mathrm{N}_{\curvearrowright}=\mathrm{uhN}$ by relating average ability level of society (h), spending time of worker in production $(\mathrm{u})$ and demand of labor force in country $(\mathrm{N})$. In this case, production function has turned into as below (Lucas, 1988):

$Y=F(K, u h N)$

According to Lucas, increase of worker ability is related with time falling outside of working time (1-u). Then, human capital accumulation equation is as follows:

$h=h e ́(1-u)$ (é amortization ) 
Importance which human capital carried has pointed out importance of the mission which government undertake about this subject. The most important mission of government is to provide qualified primary education to public. Emphasized in here is the extension of primary education time. Extension of primary education time has affected the economic growth by three ways:

a. More educated manpower has an important role in adapting and developing new technologies.

b. It will cause in increase of physical capital investments.

c. More educated population will result in decrease of fertility rate and families may invest more in their children.

In the development process of countries, Human Development Report 1994 started to explain human development indices. Human Development Indices (HDI) published by UNDP since 1990 focused on 3 main indicators.

a. Long and healthy life measured by life expectancy at birth,

b. Literacy rate and schooling rate,

c. Income per capita converted to purchasing power (Çolak et al., 2007).

Romer's study that is accepted as beginning of Intrinsic Growth Models has based on Arrow who approach in the direction of internalization of technologic development in the process of growth and firstly reveals the effect of learning by doing in the process growth. Arrow has argued that contribution of increase in information production by learning by doing will be more than contributions which it provides in specific to company (Ercan, 2000:132). Romer had determined that technologic development became intrinsic in economic model and investments which are made increased the technologic information, so it was used as free input in other economic models and this spread to general of sector as a result of spill-over (Kar and Ağır, 2005).

Below points have been pointed out about technology that is taken as intrinsic to model and using information in intrinsic growth models:

Consumers are not opponent to each other in using information and nobody had been excluded.

a. The extent to which economical units had benefited from information that come out as a result of technological development is extremely important.

b. If technologic externalities come into question, it is fact that private sector will not draw into production of information and market will fail.

c. There is relation between technologic development and physical and human capital investments (Kibritçioğlu, 1998).

Romer had taken the indicator of produced information as capital stock in process in the country. This means that the more investment made in that country before, more economic information will be produced. When production function is improved like this, increasing yields has been discussed for capital under definite assumptions. Therefore, when more 
investments are done, yield of every new investment will be more than before one (Berber, 2006).

In search that Kar and Taban (2003) made on intrinsic growth, while they emphasize that education and social security expenditures have positive effect on economic growth in Turkey, they affected negatively on health and infrastructural investments. Therefore, result had been found as that education and social security expenditures are distributed efficiently while health and infrastructural expenditures are distributed insufficiently.

\section{Literature Review}

In the international growth literature, the impact of human capital on economic growth is frequently explored. The positive relationship between the variables used in most of the studies examining the relationship between human capital and economic growth was determined. The studies examining the relationship between economic growth and human capital is divided into studies and international studies conducted in Turkey.

Table 1. National Studies Investigating the Relationship Human Capital and Economic Growth

\begin{tabular}{|c|c|c|c|}
\hline Author(s) & Period & Method & Results \\
\hline $\begin{array}{c}\text { Taban and Kar } \\
\text { (2006) }\end{array}$ & 1969-2001 & Johansen Cointegration & $\begin{array}{l}\text { Human Capital Education } \\
\text { Index } \leftrightarrow \text { Economic Growth }\end{array}$ \\
\hline $\begin{array}{l}\text { Ay and Pinar } \\
\text { (2008) }\end{array}$ & $1950-2000$ & $\begin{array}{c}\text { Johansen Cointegration and } \\
\text { Causality Test }\end{array}$ & Positive relationship \\
\hline $\begin{array}{l}\text { İzgi and Arslan } \\
\text { (2008) }\end{array}$ & $1988-2008$ & Least Squares Method & $\begin{array}{l}\text { Positive and Significant } \\
\text { Relationship }\end{array}$ \\
\hline Afşar (2009) & 1963-2005 & Granger Causality & $\begin{array}{l}\text { Education Investments } \rightarrow \\
\quad \text { Economic Growth }\end{array}$ \\
\hline $\begin{array}{c}\text { Varsak and } \\
\text { Bakırtaş (2009) }\end{array}$ & $1970-2008$ & $\begin{array}{l}\text { Johansen Cointegration Test, } \\
\text { Vector Error Correction (VEC) } \\
\text { and Variance }\end{array}$ & $\begin{array}{c}\text { Positive effect on } \\
\text { education expenditure and } \\
\text { income distribution }\end{array}$ \\
\hline & & Separation Analysis & \\
\hline $\begin{array}{l}\text { Şimşek and } \\
\text { Kadılar (2010) }\end{array}$ & $1960-2004$ & Boundary Test Approach & $\begin{array}{l}\text { It is concluded that the } \\
\text { increase in growth } \\
\text { nourishes human capital. }\end{array}$ \\
\hline $\begin{array}{l}\text { Altıntaş and } \\
\text { Çetintaş (2011) }\end{array}$ & $1970-2007$ & Granger Causality & $\begin{array}{l}\text { Positive and Significant } \\
\text { Relationship }\end{array}$ \\
\hline $\begin{array}{l}\text { Çalışkan et.al., } \\
\text { (2013) }\end{array}$ & $1923-2011$ & Johansen Cointegration & Positive relationship \\
\hline Koç (2013) & 2012 & Panel Data Analysis & Positive relationship \\
\hline Topallı (2017) & $1960-2012$ & $\begin{array}{l}\text { VEC Model and Toda- } \\
\text { Yamamoto Causality Test }\end{array}$ & $\begin{array}{c}\text { Human Capital Economic } \\
\text { Growth }\end{array}$ \\
\hline
\end{tabular}


Table 1 consists of empirical studies to show the effect of human capital on economic growth in Turkey. It has been concluded that human capital influences economic growth positively in all 10 studies in the table. Time series are used in this study such as Regression Analysis, Granger Causality, Vector Error Correction (VEC) and Variance Separation Analysis, Johansen Cointegration Test analyzes have been used. In these studies, variables such as human capital index and human capital education index were used as dependent variables.

Table 2. International Studies Investigating the Relationship Human Capital and Economic Growth

\begin{tabular}{|c|c|c|c|c|c|}
\hline Author(s) & Period & Country(s) & Method & & Results \\
\hline $\begin{array}{l}\text { Levin-Rault } \\
\text { (1997) }\end{array}$ & $1965-1984$ & $\begin{array}{l}30 \text { industrialized } \\
\text { countries }\end{array}$ & $\begin{array}{l}\text { Panel } \\
\text { Analysis }\end{array}$ & Data & $\begin{array}{l}\text { Long } \\
\text { Relationship }\end{array}$ \\
\hline $\begin{array}{l}\text { In and } \\
\text { Doucouliagos } \\
(1997)\end{array}$ & $1949-1984$ & USA & $\begin{array}{l}\text { Granger } \\
\text { Causality }\end{array}$ & & $\begin{array}{l}\text { Strong causality } \\
\text { relationship }\end{array}$ \\
\hline $\begin{array}{l}\text { Brempong et.al., } \\
\text { (2006) }\end{array}$ & $1960-2000$ & African countries & $\begin{array}{l}\text { Panel } \\
\text { Analysis }\end{array}$ & Data & $\begin{array}{l}\text { A positive } \\
\text { meaningful } \\
\text { relationship }\end{array}$ \\
\hline Sarkar (2007) & $1970-1987$ & 92 Countries & $\begin{array}{l}\text { Panel } \\
\text { Analysis }\end{array}$ & Data & Positive Impact \\
\hline $\begin{array}{l}\text { Baharumshah } \\
\text { and Almasaied } \\
(2009)\end{array}$ & $\begin{array}{l}\text { 1974-2004 } \\
\text { Quarterly } \\
\text { data }\end{array}$ & Malezya & ARDL mo & deli & Positive Impact \\
\hline Bal et.al. (2014) & $1995-2011$ & $\begin{array}{l}\text { BRICS countries and } \\
\text { Turkey }\end{array}$ & $\begin{array}{l}\text { Panel } \\
\text { Analysis }\end{array}$ & Data & $\begin{array}{l}\text { Long-term } \\
\text { relationship }\end{array}$ \\
\hline $\begin{array}{l}\text { Manga et.al., } \\
\text { (2015) }\end{array}$ & 1995-2011 & $\begin{array}{l}\text { BRICS countries and } \\
\text { Turkey }\end{array}$ & $\begin{array}{l}\text { Panel } \\
\text { Analysis }\end{array}$ & Data & $\begin{array}{l}\text { Long-term } \\
\text { relationship }\end{array}$ \\
\hline Pelinescu (2015) & $2000-2012$ & EU Member States & $\begin{array}{l}\text { Panel } \\
\text { Analysis }\end{array}$ & Data & $\begin{array}{l}\text { A positive } \\
\text { meaningful } \\
\text { relationship }\end{array}$ \\
\hline
\end{tabular}

Table 2 presents the studies on the relationship between human capital and economic growth in the world. In the results obtained from 8 studies, it was determined that there is a strong causal relationship and positive relationship between human capital and economic growth. It is observed that human capital positively affects economic growth in world studies.

\section{Method}

Annual data between period of 1990-2016 belonging to 5 Asian Countries (Hong Kong, Japan, China, Singapore, and Korea) had been used in the study. To show the economic growth, GDP had been used as dependent variable, gross fixed capital formation, life expectation at birth and humanitarian development index had been used as independent variable. Logarithms of all variables except humanitarian development index had been included to study. Gauss 10 program and codes that are written for this program had been used for the analysis. 
The model to be estimated in the study is as follows:

$\operatorname{loggdp_{it}}=\alpha_{i t}+\beta_{1} h_{d i} i_{i t}+\beta_{2} \log c a p_{i t}+\beta_{3} \operatorname{logleb}+e_{i t}$

For the variables, cross-sectional dependency and homogeneity tests were performed first. Cross-sectional dependency and unit root tests of homogeneity testing are not considered when selecting, which will make the results of the analysis performed unbiased and consistent. While there is cross- sectional dependency between the series, analysis without consideration of this situation significantly affects the results to be obtained (Peseran, 2004).

\section{Homogeneity Test}

The homogeneity test is being investigated by delta tests of Peseran and Yamagata (2008). Under the absence hypothesis of slope homogeneity, error terms exhibit a normal distribution of $\sqrt{N} / T \rightarrow \infty$ so Peseran and Yamagata's delta_tilde statistic shows a standard normal distribution. For the small sample, Peseran and Yamagata (2008) suggested a corrected delta_tilde statistic. This statistic also has normal distribution characteristics. Therefore, if the probability values of the test statistics are less than the significance level of 0.05 , the null hypothesis that the slope coefficients are homogeneous will be rejected. The zero and alternative hypotheses of the homogeneity test, which allows the slope coefficients to be tested for homogeneity or heterogeneity for each country, are as follows:

$\mathrm{H}_{0}$ : The slope coefficients are homogeneous

$\mathrm{H}_{1}$ : The slope coefficients are not homogeneous

Table 3. Results of Homegeneity Test

Test Statistic

19.897

21.492
Probability

delta_tilde

delta_tilde_adj

Note: ${ }^{*}, * * * * *$ indicate significance levels of $10 \%, 5 \%$ and $1 \%$, respectively.

The null hypothesis that the slope coefficients are homogeneous is rejected because the probability values of delta and corrected delta test statistics according to Table 3 are smaller than 0.05 significance level. So the slope coefficients are heterogeneous.

\section{Cross-Sectional Dependence Test}

The existence of cross-section dependency; when the time dimension is larger than the crosssection size; Peseran (2004) is controlled by CDLM2 when the time dimension is equal to the cross-section size by Breusch-Pagan (1980) CDLM1 test and by Peseran (2004) CDLM test when the time dimension is smaller than the cross-section size by the CDLM1 test. These tests deviate when the group mean is different from zero. The LM test statistic is as follows:

$L M=T \sum_{i=1}^{N-1} \sum_{j=i+1}^{N}\left(\hat{\rho}_{i j}^{2}\right) \sim \frac{\chi_{N(N-1)}^{2}}{2}$

Peseran and Yamagata (2008) corrected this deviation by adding the variance and the mean to the test statistic. For this reason, the nominal deviation is expressed as corrected LM test (LMadj). LMadj statistic is as follow: 


$$
L M_{a d j}=\left(\frac{2}{N(N-1)}\right)^{1 / 2} \sum_{i=1}^{N-1} \sum_{j=i+1}^{N} \hat{\rho}_{i j}^{2}\left(\frac{(T-K-1) \hat{\rho}_{i j}-\hat{\mu}_{T i j}}{v_{T i j}}\right) \sim N(0,1)
$$

The zero and alternative hypotheses of the cross-section dependency test that test the existence of cross-sectional dependence in the study is as follows:

$\mathrm{H}_{0}$ : There is no cross-section dependency.

$\mathrm{H}_{1}$ : There is cross-section dependency.

When the probability value obtained in the test result is less than 0.05 , the $\mathrm{H}_{0}$ hypothesis is rejected at the level of $5 \%$ significance and it is decided that there is cross-section dependency (Pesaran and Yamagata, 2008).

The presence of cross-section dependency between variables is shown in Table 4 below.

Table 4. Cross Sectional Dependence

\begin{tabular}{lll}
\hline Constant & Test Statistic & p-value \\
\hline & & \\
CD 1 lm $(B P, 1980)$ & 20.852 & $0.022^{* * *}$ \\
CDlm(Peseran,2004) & 2.427 & $0.008^{* * *}$ \\
CD (Peseran, 2004) & 2.631 & $0.004^{* * * *}$ \\
LMadj (PUY, 2008) & 2.812 & $0.002^{* * * *}$ \\
\hline
\end{tabular}

Note: ${ }^{*},{ }^{* *},{ }^{* * *}$ indicate significance levels of $10 \%, 5 \%$ and $1 \%$, respectively.

$\mathrm{H}_{0}$ hypotheses were strongly rejected as the probability values were smaller than 0.05 , as seen in Table 4. It has been decided that there is a cross-section dependency in the series. In this case, second generation unit root tests that consider cross-sectional dependency and can be applied for heterogeneous panels at the same time are going to be used while unit root specifications of series were searched.

\section{Unit Root Tests}

Panel unit root tests which are frequently used in the literature are Levin et al. (2002) and Im, Pesaran and Shin (1997). These tests are described as first-generation unit root tests in the literature and do not consider cross-section dependency. Thus, despite commonly mentioned the mutual interaction between economic variables; first generation unit root tests assume cross-section dependency of the panel is independent.

In the study, since it's detected a cross-sectional dependence among panel countries, one of the second-generation considering cross-sectional dependence unit root tests developed by Hadri- Kruzomi is used to analyse the stationarity of the series.

The Hadri-Kruzomi (2012) test was developed as a panel unit root test that takes into account the cross-section dependency of the KPSS test in the time series. The test statistics calculated as follows:

$Z_{A}^{S P C}=\frac{1}{\hat{\sigma}_{i S P C}^{2} T^{2}} \sum_{t=1}^{T}\left(S_{i t}^{W}\right)^{2}$ 
$Z_{A}^{L A}=\frac{1}{\hat{\sigma}_{i L A}^{2} T^{2}} \sum_{t=1}^{T}\left(S_{i t}^{W}\right)^{2}$

Unit root hypotheses are given below (Hadri and Kruzomi, 2012):

$H_{0}: \emptyset_{i} \neq 0$ : Series is not stationary.

$H_{0}: \varnothing_{i}=0:$ Series is stationary.

Table 5 below gives the Hadri-Kruzomi panel unit root test results.

Table 5. Hadri \& Kurozumi Panel-KPSS Unit Root Test

\begin{tabular}{lll}
\hline Levels & Constant & \\
& Statistic & p-value \\
loggdp & & \\
ZA_spc & -0.9181 & 0.8207 \\
ZA_la & -0.0251 & 0.5100 \\
hdi & & \\
ZA_spc & -1.7640 & 0.9611 \\
ZA_la & -1.4492 & 0.9264 \\
logcap & & \\
ZA_spc & -2.3861 & 0.015 \\
ZA_la & -2.8636 & 0.9646 \\
logleb & & \\
ZA_spc & 22.3061 & $0.000^{*}$ \\
ZA_la & 539.358 & $0.000^{*}$ \\
\hline
\end{tabular}

${ }^{*}$ means that it is stationary in the first consciousness.

According to the results in Table 5; all variables except for life expectancy at birth seem to be stationary. After investigating the homogeneity and stability of the panels, a panel causality test was carried out according to the information obtained.

\section{Causality Test}

Panel Fisher test developed by Emirmahmutoğlu and Köse (2011) relies on the time series' Toda-Yamamoto (1995) causality test logic. Superior characteristic of this test is I (0) and I (1) series can be analysed together.

In the first step following model estimation is done:

$Z_{i, t}=U_{i}+A_{i 1} Z_{i, t-1}+\cdots+A_{i k} Z_{i, t-k_{i}}+\sum_{l=k_{i}+1}^{k_{i}+\operatorname{dmax}_{i}} A_{i l} Z_{i, t-1}+u_{i, t}$

$i=1,2,3 \ldots \ldots . . N, t=1,2,3 \ldots \ldots \ldots . T$

When null hypothesis shows there is not a causality relationship in the panel, alternative hypothesis shows at least one series have a causality relationship between variables (Emirmahmutoğlu and Köse, 2011). 
Table 6. Emirmahmutoğlu and Köse (2011) Panel Fisher Causality Test

\begin{tabular}{lll}
\hline Variables & Statistic & p-value \\
loggdp $\rightarrow$ hdi & 18.444 & $0.048^{* *}$ \\
hdi $\rightarrow$ loggdp & 14.840 & 0.138 \\
logleb $\rightarrow$ loggdp & 18.631 & $0.045^{* *}$ \\
loggdp $\rightarrow$ logleb & 36.600 & $0.000^{* * *}$ \\
hdi $\rightarrow$ logleb & 17.206 & $0.070^{*}$ \\
logleb $\rightarrow$ hdi & 19.736 & $0.032^{* *}$ \\
logcap $\rightarrow$ logleb & 44.122 & $0.000^{* * *}$ \\
logleb $\rightarrow$ logcap & 10.339 & 0.411 \\
hdi $\rightarrow$ logcap & 18.069 & $0.054^{*}$ \\
logcap $\rightarrow$ hdi & 11.162 & 0.345
\end{tabular}

Note: ${ }^{* * *},{ }^{* * *}$ indicate significance levels of $10 \%, 5 \%$ and $1 \%$, respectively.

According to Table 6 since bootstrap p-value values are less than 0.05, null hypothesis is rejected by $5 \%$ significance level. With this test, the relationship between causality between economic growth, human capital, life expectancy at birth and capital variables is investigated. One-way causality from economic growth to human development index has been identified.

\section{Conclusion}

The most important specification that developed countries differ from developing countries is high information and ability level of human capital which developed countries have. Human capital is information, skill and ability that help individual to increase efficiency in economic activities. If human capital that person has is qualified, it has been the reason of country's development and improvement as directly or indirectly. Making real of economic development of developing countries depends on firstly improving their human capital.

In this study, relation between human capital and economic growth had been analyzed for 5 ASIAN member countries with the help of panel data analysis by using annual data between era of 1990 and 2016.

In the research, cross-sectional dependency and homogeneity tests had been done for variables at first. Since cross-sectional dependency was found between countries constituting the panel, for examining stability of series, Hadri-Kruzomi test which is one of the second-generation unit root test that considers the cross-sectional dependency and for causality test, Emirmahmutoğlu and Köse (2011) causality test had been used. According to results, unidirectional causality relation had been determined from economic growth to humanitarian development index.

Being fact that human capital activates the economic growth has revealed that there is need to give importance to develop human capital. Especially, there is need that countries which are in goal of catching the developed countries consider the human capital more. Education has officiated many important missions such as increasing individual level of income, enhancement of income distribution and decreasing poverty beyond providing economic growth. Within this context, enhancements should have been done in fields developing human 
capital, increasing education quality and taking additional precautions that will increase the income of human capital have been suggested.

\section{Kaynakça}

Afşar, M. (2009). Türkiye'de eğitim yatırımları ve ekonomik büyüme ilişkisi. Anadolu Üniversitesi Sosyal Bilimler Dergisi 9(1), 85-98.

Altıntaş, H. \& Çetintaş, H. (2011). Türkiye'de ekonomik büyüme, beşeri sermaye ve ihracat arasındaki ilişkilerin ekonometrik analizi: 1970-2005. Erciyes Üniversitesi İktisadi ve İdari Bilimler Fakültesi Dergisi, Sayı 36, 33-56.

Ay, A., \& Yardımcı, P. (2008). Türkiye'de Beşeri Sermaye Birikimine Dayalı AK Tipi İçsel Büyümenin VAR Modeli İle Analizi (1950-2000). Maliye Dergisi, Sayı:155, 39-54.

Baharumshah, Ahmad, Zubaidi \& Almasaied, Suleiman, W. (2009). Emerging Markets Finance $\mathcal{E}$ Trade / 45(1), January-February, pp.90-102.

Bal, H., Algan, N., Manga, M. \& Kandır, E. (2014). Beşeri Sermaye ve Ekonomik Büyüme İlişkisi: BRICS Ülkeleri ve Türkiye Örneği. International Conference On Eurasian Economies, (http://avekon.org/papers/923.pdf 17/11/2015'de erişildi).

Berber, M. (2006). İktisadi Büyüme ve Kalkınma. 6. Baskı, Derya Kitabevi, Trabzon, 180.

Brempong, Kwabena, Gyimah, Oliver, Paddison \& Workie, M. (2006). Higher Education and Economic Growth in Africa. Journal of Development Studies 42(3), pp. 509-529.

Breusch, T.S. \& Pagan, A.R. (1980). The Lagrange Multiplier Test and Its Application to Model Specification in Econometrics. Review of Economic Studies 47, pp.239-254.

Çalışkan, Ş., Karabacak, M., \& Meçik, O. (2013). Türkiye' de Eğitim-Ekonomik Büyüme İlişkisi: 1923-2011 (Kantitatif Bir Yaklaşım). Yönetim Bilimleri Dergisi 11(21):29-48.

Çolak, Ö. F. \& Tokatlığlu İ. (2007). İktisada Giriş. Gazi Kitabevi, Ankara.

Emirmahmutoğlu, F. \& Köse, N. (2011). Testing for Granger Causality in Heterogeneous Mixed Panels. Economic Modelling, 28: 870-876.

Ercan, Yener, N. (2000). Planlama Dergisi Özel Sayı. (http://ekutup.dpt.gov.tr/planlama/42nciyil/ercanny.pdf), (03.10.2018).

Hadri, Kaddour \& Kurizomi, E. (2012). A Simple Panel Stationarity Test in the Presence of Serial Correlation and a Common Factor. Economics Letter, Say1:115, pp.31-34.

Im, Kyung So, Pesaran, M. Hashem \& Shin, Y. (2003). Testing for Unit Roots in Heterogeneous Panels. Journal of Econometrics 115, pp.53-74.

In, F. \& Doucouliagos, C. (1997). Human Capital Formation and US Economic Growth: a Causality Analysis. Applied Economics Letters, Taylor \& Francis Journals 4(5): 329-331.

İzgi, B. B., \& Arslan, İ. (2008). Türkiye'de genç işsizliği, eğitim ve büyüme ilişkisi (1988-2008). 2. Ulusal İktisat Kongresi İzmir,1-11.

Kar, Muhsin \& Ağır, H. (2003). Türkiye' de Beşeri Sermaye ve Ekonomik Büyüme: Nedensellik Testi. (http://www.elelebizbize.com/ekutuphane/muhsinkar/turkiyedebeserisermaye.pdf), (10.09.2018). 
Kar, Muhsin \& Taban, S. (2003). Kamu Harcama Çeşitlerinin Ekonomik Büyümeye Etkisi. Ankara Üniversitesi Siyasal Bilgiler Fakültesi Dergisi, Cilt: 58(3).

Karabulut, K. \& Emsen, Ö. S. (1997). Kalkınma Teorileri ve Geliştirilen Son Büyüme Modeli: Yeni Büyüme Teorisi. Atatürk Üniversitesi İ.I.B.F. Dergisi, Cilt: 11(34).

Kibritçioğlu, A. (1998). İktisadi Büyümenin Belirleyicileri ve Yeni Büyüme Modellerinde Beşeri Sermayenin Yeri. Ankara Üniversitesi Siyasal Bilgiler Fakültesi Dergisi, Cilt: 53, No: 1-4, Ocak- Aralık, 11.

Koç, A. (2013). Beşeri Sermaye ve Ekonomik Büyüme İlişkisi: Yatay Kesit Analizi ile AB Ülkeleri Üzerine Bir Değerlendirme. Maliye Dergisi, Sayı 165.

Levin, A. L. \& Raut, L.K. (1997). Complementarities between Exports and Human Capital in Economic Growth: Evidence from the SemiIndustrialized Countries. Economic Development and Cultural Change (46):15574.

Levin A, Lin, C. F., \& Chu, Chia-Shang, J. (2002). Unit Root Tests in Panel Data: Asymptotic and Finite-Sample Properties. Journal of Econometrics, V.108, p.1-24.

Lucas, R. (1988). On the Mechanichs of Economic Development. Journal of Monetary Economics, 3-42.

Manga, M., Bal, H., Algan, N. \& Kandir, E. D. (2015). Beşeri Sermaye, Fiziksel Sermaye ve Ekonomik Büyüme İlişkisi: BRICS Ülkeleri ve Türkiye Örneği. Ç.Ü. Sosyal Bilimler Enstitüsü Dergisi, Cilt 24, Sayı 1, 2015, pp.45-60.

Pelinescu, E. (2015). The impact of human capital on economic growth. Procedia Economics and Finance 22, 184-190.

Peseran, H., M. (2004). General Diagnostic Tests for Cross Section Dependence in Panels. Discussion Paper No. 1240 August, p.5.

Pesaran, H. M. \& Yamagata, T. (2008). Testing Slope Homogeneity in Large Panels. Journal of Econometrics, 142, pp.50-93.

Romer, P. M. (1990). Are Nonconvexities Important Understanding Growht?. AEA Papersand Proceedings, 80:2, 97-103.

Sarkar, D. (2007). The Role of Human Capital In Economic Growth Revisited. Applied Economics Letters, 2007, 14, pp.419- 423.

Şimşek, M., \& Kadılar, C. (2010). Türkiye'de beşeri sermaye, ihracat ve ekonomik büyüme arasındaki nedensellik analizi. C.Ü İktisadi ve İdari Bilimler Dergisi 11(1), 115-140.

Taban, S., \& KAR, M. (2006). Beşeri sermaye ve ekonomik büyüme: Nedensellik analizi 19692001. Anadolu Üniversitesi Sosyal Bilimler Dergisi, 159-182.

Toda, Hiro Y. \& Yamamoto T. (1995). Statistical Inferencein Vector Autoregression with Possibly Integrated Processes. Journal of Econometrics 66, 225-250.

Topallı, N. (2017). Beşeri Sermaye ve Ekonomik Büyüme Arasındaki İlişki: Türkiye Örneği. Ömer Halisdemir Üniversitesi İktisadi ve İdari Bilimler Fakültesi Dergisi, Cilt-Sayı: 10(2), pp:129140.

Varsak, S. \& Bakirtaş, İ. (2009). Ekonomik Büyüme Üzerinde Beseri Sermayenin Etkisi: Türkiye Örneği. Dumlupınar Üniversitesi Sosyal Bilimler Dergisi, Say1:25, 49-59. 